\title{
Jefferson
}

Thomas Jefferson University

HOME OF SIDNEY KIMMEL MEDICAL COLLEGE

Jefferson Journal of Psychiatry

Volume 10 | Issue 2

Article 13

June 1992

\section{Little Elephant Learns About Sex}

Judith Watt, M.D.

Thomas Jefferson University Hospital

Follow this and additional works at: https://jdc.jefferson.edu/jeffjpsychiatry

Part of the Psychiatry Commons

Let us know how access to this document benefits you

\section{Recommended Citation}

Watt, M.D., Judith (1992) "Little Elephant Learns About Sex," Jefferson Journal of Psychiatry. Vol. 10 : Iss. 2 , Article 13.

DOI: https://doi.org/10.29046/JJP.010.2.010

Available at: https://jdc.jefferson.edu/jeffjpsychiatry/vol10/iss2/13

This Article is brought to you for free and open access by the Jefferson Digital Commons. The Jefferson Digital Commons is a service of Thomas Jefferson University's Center for Teaching and Learning (CTL). The Commons is a showcase for Jefferson books and journals, peer-reviewed scholarly publications, unique historical collections from the University archives, and teaching tools. The Jefferson Digital Commons allows researchers and interested readers anywhere in the world to learn about and keep up to date with Jefferson scholarship. This article has been accepted for inclusion in Jefferson Journal of Psychiatry by an authorized administrator of the Jefferson Digital Commons. For more information, please contact: JeffersonDigitalCommons@jefferson.edu. 


\title{
Little Elephant Learns About Sex
}

\author{
WHERE BABIES GOME FROM \\ Stories to Help Parents Answer \\ Preschoolers Questions About Sex \\ Martin Silverman, M.D. and Harriet Ziefert \\ Illustrated by Claire Schumacher \\ Random House Press \\ $1989, \$ 19.00$
}

\section{by Judith Watt, M.D.}

Not yet a true connoisseur of children's books, I have to pause to consider, what makes one more appealing than another? Is it simply that some have such eloquent illustrations, or, are some plots more playful, and some texts more stimulating to the active adult imagination? Perhaps it is that some children's books inspire grown-ups to re-experience Lilliputian epiphanies, clarifying insights into our own childhood memories. I am pleased to introduce one such memorable book for children that exemplifies each of these factors, a very slender volume of the most appealing kind.

This hard-cover book of whimsical animal tales is only fifty pages, featuring large, subtly expressive watercolors, and short, simple text. The elegant brainchild of two talented New York psychoanalysts, it was designed to "Help Parents Answer Preschoolers Questions About Sex." Martin Silverman, M.D., is chairman of the Child Analysis Program at the Psychoanalytic Institute at New York University Medical Center. His colleague, and co-author, Harriet Ziefert, is a research candidate there. Together, they have crafted an unusually nuanced storybook experience for parents. It is a tactful synthesis of fantasied fiction and familial fact.

In tasteful allegorical style, the primer addresses a variety of questions concerning sex, conception, fetal development and childbirth. The language is simple, and jargon-free. But the stories do more than teach the facts. They also serve as models of "good enough" communication and conflict resolution within a typical postFreudian, post-Mahlerian elephant's nuclear family.

Four short stories unfold, each one centering around Kikki, the monkey, and his non-primate friend, Little Elephant. In the first story, "Whose Big Egg?," this unlikely duo sleuths through what appears to be an African jungle, exquisitely watercolored by Claire Schumacher, in search of the mysterious mother of a large yellow egg. En route, readers learn that giraffes, antelopes and baboons don't lay their eggs, but instead "grow their babies inside their bodies." And also, that snakes, turtles, and bird babies "come from outside their mother's bodies." The missing link 
here, human beings, is absent from both the illustrations and text until the very back of the book, in the question and answer section. Still, with expert simplicity, the authors deftly prepare the ground for the delicate process of talking openly with preschoolers about sexuality, conception, fetal development and childbirth.

In the second vignette, "Little Elephant Butts In," the illustrations show a variety of animal pairs mating amidst the African brush. When Little Elephant questions her, Mother Elephant explains that the animals were "doing something special that made them both feel good." In dismay, Little Elephant says what many preschoolers would say, "But it looked like they were fighting!" Later, when Little Elephant charges out of the brush and "butts headfirst into his mother's side," she gently explains that "some things you just can't do." While firmly reinforcing the intergenerational boundaries, the text empathically explores Little Elephants reactions. In this way, readers are privy to a sensible resolution of the classical Oedipal conflict.

A few disappointments face the discriminating reader in the third section of the book. It is entitled, "Boys and Girls - What's the Difference?" Rather than facing the issues of gender envy squarely and mutually, the story is told only from the little boy elephant's perspective. And, rather than acknowledging his disappointment at learning that babies will never grow inside his own body, this is unfortunately denied. Also in this section, preschoolers may gain the mistaken impression that the only sexually active zebra is a married zebra. Perhaps these points suggest the possibility of a sequel, with more stories addressed to preschoolers questions about nontraditional families in the modern setting.

Notably lacking from the book are anatomical illustrations of any kind. Perhaps another book will be sensitive to fulfilling pre-schoolers' needs for accurate pictures of male and female anatomy. Factual drawings of external anatomy would fit comfortably into the question section at the back of the book, and one wonders at their absence. It would be a meaningful addition to this text. As long as pre-schoolers are left without seeing basic anatomical differences openly displayed, confusion will persist. And, children may wonder whether some adults are made uncomfortable by some very basic matters of fact.

The fourth and final saga, "A New Baby on The Way," is stronger, and more satisfying. It addresses some of the issues inherent in sibling rivalry. When Little Elephant learns that his mother is pregnant with another baby, he stamps his foot and wants to return to mother's womb. By attending to his feelings and not denying them, Little Elephant's mother helps him to understand that he feels sad and jealous. Feeling understood, his curiosity about life returns resulting in playfulness, followed by affection, and finally growing into deep pride in the fact of his becoming a big brother. Again readers are treated to a sensible resolution to the familial feelings of rivalry.

Despite its few shortcomings, this children's book provides a pleasurable reading experience for adults, and for avidly curious preschoolers. Sensitive to inquisitive minds, there is the short question-and-answer section at the very back, and it is well 
worth waiting for. It is all text, no illustrations, and effectively gets down to the business of well-worded answers and questions. Among the memorable questions is the notable, "What did I eat when I was a baby inside you?". In sum, I highly recommend this book for aficionados of the analytic process, and perhaps for others as well. 